\title{
The Influence of Cognition on the Knobe Effect of Juvenile Intention in the Field of Social Rules
}

\author{
Jing Lin, ${ }^{1,3}$ Jun Tao, ${ }^{2}$ Hong Fu ${ }^{1}$ \\ 1. Nanjing Normal University, Nanjing, China \\ 2. Nanjing Finance and Economics Higher Vocational and Technical School, \\ Nanjing, China \\ 3. Nanjing Research Center of Education Science, Nanjing, China
}

\begin{abstract}
We set up experimental stories that violated and abided by domain rules, negative and positive side effects, and selected 850 middle school students to read stories and answer questions to explore the characteristics of the juvenile Knobe effect under cognitive conditions in three single social rules. The results showed that: (1) When the teenagers violate the domain rules, the Knobe effect is exhibited in the three types of events, and in the case of complying with the domain rules, only the Knobe effect occurs in the personal field, and (2) The domain rules are observed. Under the positive side effects, boys are more inclined to judge the intentions of positive side effects in the field of ethics and customs than in girls. (3) With the development of age, the juveniles' judgments on the side effects are also inverted $U$-shaped, which is consistent with the development of moral judgment age. The conclusion is that adolescents have only an incomplete Knobe effect in a single-field event, and the specific performance is influenced by domain rules and domain types.
\end{abstract}

Sci Insigt Edu Front 2019; 4(1):355-368.

Doi: 10.15354/sief.19.ar126

Keywords: Knobe Effect; Social Rule Cognition; Intention Judgment;

Moral Development

About the Authors: Jing Lin, College of Education Science, Nanjing Normal University; Nanjing Research Center of Education Science, Email: 952198256@qq.com;

Jun Tao, Nanjing Finance and Economics Higher Vocational and Technical School, Email: 547503463@qq.com; 
$\mathrm{T}$

HE Knobe effect, also known as the side-effect effect, is an asymmetry found by Jusha Knobe about intentional judgment. If the consequences of an action are predictable, but not expected to occur, then the consequences of such behavior are called side effects. The Knobe effect refers to the phenomenon that people tend to think of bad side effects as intentional, and tend to think that good side effects are unintentional (Knobe, 2003).

The Knobe effect discovered by Knobe (2003) illustrates the influence of moral valence on intentional judgment. The moral valence theory holds that moral judgment is first. In the case of behavior that has been judged to be bad, as long as the result is foreseen (i.e. known Side effects, beliefs about intentions, judge behavior is intentional, and when judgment behavior is good, beliefs with side effects do not indicate intentionality, but also other aspects such as expectations and skill components. information. The evaluation of the reward and punishment characteristics occurs after the intentional judgment, and is based on the function of the intentional folklore concept: the behavior with stronger intentions should be more rewarded or punished. But moral parity has a major flaw. There is no clear line between whether morality and behavior should be rewarded or punished. For example, Konbe and Mendlow (2004) used negative side effects in a neutral experimental scenario (Director Long to improve the performance of the A region, foresight will affect the performance of the $\mathrm{B}$ region), most of the participants still judged that the chairman is intentional, but most of the participants (80\%) believe that the chairman's behavior is Unrecognized and impunity, although the study cannot deny the role of moral valence theory, but it also exposes the limitations of moral valence theory, suggesting that the mechanism of moral valence theory may not be so simple, it needs to be set. More complex experimental scenarios on moral evaluation are studied in depth.

The emergence of the Knobe effect shows that people are not so rational when making intentional judgments and the nature of behavioral morality affects people's intentional judgment. Although there is no unified conclusion on the theoretical interpretation of Knobe effect, we can find out the different theoretical interpretations. We can find that the biggest controversy lies in whether it is related to moral judgment. Most of the theories recognize the special significance of moral judgment, and believe that the potential application value of moral judgment leads to asymmetric intention judgment. The difference between these theories lays in the mechanism of the special function, including Knobe's moral potency theory, Nadelhoffer, etc. Interpretation of human psychological prejudice, practical interpretation of the language of Adams and Steadman, etc.; and some theories that the Knobe effect is actually unrelated to moral issues, which is just an ordinary attribution process, such as Machery's trade-off assumption (Du \& Zheng, 2010). 
Ethical potency theory (Knobe, 2003; Knobe \& Mendlow, 2004; Knobe, 2006) emphasizes the relationship between intention and moral judgment. This theory explains that people's judgment of behavioral intention is determined by two attribution processes. Judging, the second step is based on the moral valence of behavior, and then the intention judgment. When the behavior is judged to be bad, only the subjectively predicts the result, that is, the belief component (the actor knows) in the intention, can determine that the actor is intentional and purposeful; but if the behavior is judged to be good personal beliefs or experiences do not fully explain that behavior is intentional, but also need to examine other information components such as expectations and habits. The theory holds that the judgment of whether the behavior should be rewarded or punished occurs after the judgment of the behavioral intention; the judgment of the moral valence of the behavior is made intuitively. The subsequent reward and punishment judgment belongs to a more rational moral and responsibility judgment. Based on this theoretical explanation, there is also a constructive assumption that intentional judgment may be heuristic (Feltz, 2007). For bad behavior, people can judge it as intentional based on a small amount of information; but for good behavior, there is no such heuristic understanding, and people usually judge more comprehensively and rationally.

Nadelhoffer's (2005) psychological bias explained that the Knobe effect originated from a negative evaluation of behavioral actors in experimental situations. Negative evaluations cause people to have psychological prejudice, and thus hope to condemn the behavior implementers, and tend to judge the behavioral implementers' intentions to cause negative side effects. Similarly, if it is a positive situational condition, people's behavior evaluation of the implementer is also appraisable, positive and favorable; it also produces the psychological bias of the implementer of the reward behavior, and also tends to judge the behavior implementer is intentional, but only it is better to want to be rewarded than to want to be punished. The assertion is based on ethical considerations of conditions of different nature (positive, neutral, negative), and it is believed that it will have different effects on the judgment of behavioral intentions, but under negative conditions, the influence is more obvious. Moral judgment of behavioral intentions is not limited to simple judgments of good or bad, but it is considered more important to consider whether individual behavior is rewarded or punished.

Then, whether the influence of different moral behaviors has a side effect on the intention judgment, there is no relevant research in the literature. Therefore, this study controls the actors' factors and studies the Knobe effect from the moral evaluation of behavior. Taking adolescents as the research object, the social cognitive domain theory is selected to divide social rules or events, and the observance or violation of events in the field of social cognition is integrated into the behavior of the actors. Behavior produces a moral color. Since the age of seven, it is possible to distinguish between events or rules in three areas. And it is generally believed that the severity of moral violations is greater than the violations of customs and personal areas, and the violations of customs are greater than the violations of events in the personal field. Therefore, it is assumed that the moral field violates the lowest moral evaluation of behavior, then by the violation of the custom field, followed violations in the personal field. The Knobe 
effect is characterized by cognitive influence in the field of social rules by observing or violating the domain type.

\section{Methods}

\section{Participant}

From the six middle schools in Nanjing, 108 students in the seventh grade ( 61 boys, 47 girls, average age 12.51 \pm 0.54 ), 109 in the eighth grade (51 boys, 68 girls, average age $13.44 \pm 0.54$ ), ninth grade 107 people (56 boys, 51 girls, average age 14.71 \pm 0.50 ), 213 people in grade 10 (147 boys, 66 girls, average age 15.62 \pm 0.55$), 209$ in the eleventh grade (115 boys, girls 94 Persons, 104 students in the 12th grade (25 boys, 79 girls), a total of 850 participants, (Note: Grade 10 and 11 students from ordinary high schools and vocational high schools, 12th grade students only from ordinary high schools) . Random stratified sampling was chosen on the sampling method.

\section{Experimental Materials}

According to the context framework of Knobe effect, the Knobe effect context of three single domain events was designed. Each domain situation has been designed with different stories that conform to and violations of domain rules. Each story has both positive and negative side effects. In order to control the influence of the actors, all story actors are classmates. Refer to the relevant literature (Nucci \& Turiel, 2009) and interview the students and teachers in the school to compile the corresponding experimental stories to make the story close to the real life of Chinese teenagers. The specific story frame is shown in Table $\mathbf{1 .}$

\section{Experimental Procedure}

A mixed experimental design using 3 (domain type: ethics, individual, custom) $\times 2$ (rule of nature: compliance, violation) $\times 2$ (side effects: positive, negative). The domain type is the inter-subject variable, and the three classes of each grade complete the story of different domain types. The rule nature and side-effect conditions are the internal variables of the subject. Each participant read a story that complies with the rules of the field and a rule that violates the domain. Each story includes positive and negative conditions and a total of four story scenarios are read. The following is an example of a story in which the personal domain violates the rules of the field and the side effects are positive.

On the birthday, Mingming Wang wanted to buy online game equipment with a pocket money that was accumulated for half a year. Classmate You $\mathrm{Hu}$ said to Mingming Wang: You cannot only win more online games, but also your brother can't ask for money to go online to the internet, so that his grades can be improved. Mingming Wang said: "I don't care if my brother is improving his academic performance because he has no money to go online. I only care if I can win in online games." Mingming Wang bought his pocket money for online game equipment, and his brother 


\section{Table 1. Social Rules Field Events Promise in the Experiment Story} Cloth Effect.

\begin{tabular}{|c|c|c|c|}
\hline $\begin{array}{l}\text { Domain } \\
\text { Type }\end{array}$ & $\begin{array}{l}\text { Rule } \\
\text { Nature }\end{array}$ & $\begin{array}{l}\text { Behavioral } \\
\text { Background }\end{array}$ & $\begin{array}{l}\text { Side Effects \& Specific Per- } \\
\text { formance } \\
\text { (1 = Positive, } 2 \text { = Negative) }\end{array}$ \\
\hline \multirow[t]{3}{*}{ Moral } & \multirow[t]{2}{*}{$\begin{array}{l}\text { Comply } \\
\text { With }\end{array}$} & \multirow{2}{*}{$\begin{array}{l}\text { Injured primary school stu- } \\
\text { dents on the road to the hospi- } \\
\text { tal }\end{array}$} & $\begin{array}{l}\text { 1. Class commended by the } \\
\text { school }\end{array}$ \\
\hline & & & $\begin{array}{l}\text { 2. The class was criticized by } \\
\text { the school. }\end{array}$ \\
\hline & Violation & $\begin{array}{l}\text { The exam is not good enough } \\
\text { to steal the final exam scores }\end{array}$ & $\begin{array}{l}\text { 1. My sister is encouraged } \\
\text { 2. Sister punished }\end{array}$ \\
\hline \multirow{4}{*}{$\begin{array}{l}\text { Personal } \\
\text { Field }\end{array}$} & \multirow{2}{*}{$\begin{array}{l}\text { Comply } \\
\text { With }\end{array}$} & \multirow{2}{*}{$\begin{array}{l}\text { I like to sing and sign up for } \\
\text { the singing competition. }\end{array}$} & 1. The class added points. \\
\hline & & & 2. Class points the \\
\hline & \multirow[t]{2}{*}{ Violation } & \multirow[t]{2}{*}{$\begin{array}{l}\text { I bought online game equip- } \\
\text { ment with my pocket money. }\end{array}$} & $\begin{array}{l}\text { 1. The younger brother's aca- } \\
\text { demic performance has im- } \\
\text { proved. }\end{array}$ \\
\hline & & & $\begin{array}{l}2, \text { my brother's academic per- } \\
\text { formance has dropped }\end{array}$ \\
\hline \multirow[t]{4}{*}{$\begin{array}{l}\text { Customary } \\
\text { Field }\end{array}$} & \multirow[t]{2}{*}{$\begin{array}{l}\text { Comply } \\
\text { With }\end{array}$} & \multirow[t]{2}{*}{$\begin{array}{l}\text { Require the teacher's consent } \\
\text { to change seats as required }\end{array}$} & $\begin{array}{l}\text { 1. In contrast to change seats } \\
\text { to improve the achievement of } \\
\text { students }\end{array}$ \\
\hline & & & $\begin{array}{l}\text { 2. In contrast to change seats } \\
\text { achievement of students } \\
\text { dropped }\end{array}$ \\
\hline & \multirow[t]{2}{*}{ Violation } & \multirow[t]{2}{*}{$\begin{array}{l}\text { Do not clean the table accord- } \\
\text { ing to the value specified by } \\
\text { the school }\end{array}$} & $\begin{array}{l}\text { 1. Classmates who have been } \\
\text { cleaning together have been } \\
\text { praised }\end{array}$ \\
\hline & & & $\begin{array}{l}\text { 2. Cleaning with students has } \\
\text { been criticized }\end{array}$ \\
\hline
\end{tabular}

is just like what his classmates said, because his brother can't ask Mingming Wang to spend money online, so his academic performance has improved.

Referring to previous studies ( $\mathrm{Du}, 2010$; Chen \& Geng, 2013), the problem and coding method are set as follows:

Question 1: To what extent do you agree that "Mingming Wang was intentionally letting his younger brother improve his academic performance?" This question is the question of intentional judgment, "completely disagree" to "completely agree" 5 points, the higher the score, the more obvious the tendency to make "intentional" judgment.

Question 2: How do you evaluate Mingming Wang 's purchase of online game equipment, and his younger brother's academic performance improved? The behavioral nature of the evaluation problem (see question 2), 5 points score, the higher the score, indicating that the evaluation is better.

Question 3: Mingming Wang used pocket money to buy online game equipment. His younger brother's academic performance improved. Should Mingming Wang be praised? This question is the evaluation question of behavior reward and punishment. 
In the case where the side effect is negative, the question is described as "...whether it should be condemned". In the case where the side effect is positive, the question is described as "... whether it should be praised". In the 5-point scoring method, the larger the number selected, the more obvious the reward and punishment evaluation characteristics of behavior.

Question 4: Does Mingming Wang mainly want to buy online game equipment or want his brother's academic performance to improve? This is behavioral motivation judgment problem (see question 4). There are two small questions. The first question is the judgment of the main motivation, that is, the content of the "I don't care... I only care about..." in the actor's language description, such as "I want to win in online games", The second question is the judgment of the secondary motivation, that is, the part of the actor's language description that "I don't care..." does not care, such as "thinking the younger brother to improve the academic performance", each motivation is measured separately, with 0-6 indicates from "not at all" to "completely", the greater the number, the stronger the motivation.

\section{Results}

\section{Indirect Intention of Side Effects in a Single Domain Class}

The type of field in this study is inter-group variable, so we can compare the intentional judgment of two side effects under the same field rule in a single field and the sideeffect intention of different field rules in a single field under the same side effect condition. Analysis of the characteristics of the Knobe effect, see Table 2.

It can be seen from Table 2 that when the rules of the field are observed, there are differences in the intentional judgment under the two side effects in the personal field, and the judgment is significant under the negative conditions, and there is no such significant difference in the moral field and the customary field. When the rules of the field are violated, differences in the intentional judgment of side effects occur in the moral field, the personal field, and the customary field, and the intention is judged to be significant under negative conditions.

Judging from the same side-effects, in addition to the negative conditions in the customary field, there are side effects in other fields and conditions that are intended to judge the difference in the nature of the domain rules. The side-effect behaviors in violation of the domain are more inclined to be judged as intentional as the side-effect behaviors in the field.

\section{Intention to Determine Gender Differences in Side Effects of Events in a Single Field}

To study the difference of gender variables, firstly, in each field, a paired sample $t$ test of intentional judgment scores under two side effects conditions was first carried out, 
Table 2. Intentions in Different Field Types and Domain Rules.

\begin{tabular}{|c|c|c|c|c|c|c|c|c|c|c|}
\hline \multirow{2}{*}{ Condition } & & \multicolumn{3}{|c|}{$\begin{array}{l}\text { Moral Field } \\
(N=277)\end{array}$} & \multicolumn{3}{|c|}{$\begin{array}{l}\text { Personal Area } \\
(N=295)\end{array}$} & \multicolumn{3}{|c|}{$\begin{array}{l}\text { Customary Field } \\
(N=278)\end{array}$} \\
\hline & & Neg. & Pos. & $t_{1}$ & Neg. & Pos. & $t_{2}$ & Neg. & Pos. & $t_{3}$ \\
\hline Comply & $M$ & 1.78 & 1.64 & 1.53 & 2.33 & 2.10 & $4.23^{\star *}$ & 2.40 & 2.30 & 1.02 \\
\hline $\begin{array}{l}\text { With } \\
\text { Field }\end{array}$ & $S D$ & 1.28 & 1.04 & & 1.56 & 1.32 & & 1.26 & 1.27 & \\
\hline Violation & $M$ & 2.70 & 1.95 & $7.56^{* \star}$ & 3.13 & 2.40 & $2.25^{*}$ & 2.28 & 1.72 & $6.00^{\star \star}$ \\
\hline Field & $S D$ & 1.40 & 1.08 & & 2.75 & 1.34 & & 1.36 & 1.02 & \\
\hline$t$ value & & $\begin{array}{l}-95^{\star \star} \\
\end{array}$ & $\overline{3.83^{\star *}}$ & & $\begin{array}{l}-19^{\star * *} \\
\end{array}$ & $\overline{-}-37^{\star \star}$ & & 1.31 & $7.13^{\star \star}$ & \\
\hline $\begin{array}{l}\text { Note: } t 1 \text { i } \\
\text { the moral } \\
\text { same fiel } \\
\text { tions at b } \\
\text { parison to } \\
\text { value of } 0\end{array}$ & & sono & intion & dgme & nder & wo st & ffects & les & sa & $\begin{array}{l}\text { field in } \\
\text { he } \\
\text { inten- } \\
\text { com- } \\
\text { t test } d\end{array}$ \\
\hline
\end{tabular}

and then an independent sample $t$ test was performed on the intention judgment between gender variables. The results are shown in Table 3.

From Table 3, we can see that when the violation of the domain rules, in addition to the violation of the rules of the personal field, the differences between the two side effects of the boys are not significant; when the other areas violate the rules, regardless of the intent to judge the two side effects of boys and girls, the difference in learning is significant. In addition, when obeying the rules of the field, both male and female subjects in the judgment of the personal field showed significant differences in the intentional judgment of the two side effects.

Comparing the differences between boys and girls, it is found that when the rules of the field are observed, there are significant differences in the moral field and the customary field under the conditions of positive side effects. Boys are more inclined to have intentions than the positive side effects of girls in these two fields.

\section{The Intent of the Side Effects of Events in a Single Field to Determine the Grade Difference}

The intent judgment result is the dependent variable, the grade level and the domain type are inter-group variables, the domain rules and side-effect conditions are the intersubject variables, and the repeated measurement analysis of variance results are shown in Table 4.

It can be seen from Table 4 that the main effects of the four variables of grade, domain type, domain rules, and side-effect conditions are significant, and the interaction between the two is significant with domain rules and grades, domain rules and domain types, domain rules, and side-effects; There are significant domain rules, grades, and domain types; domain rules, side-effect conditions, and domain types; the interact- 


\begin{tabular}{|c|c|c|c|c|c|c|c|}
\hline \multirow[t]{2}{*}{$\begin{array}{l}\text { Domain } \\
\text { Type }\end{array}$} & & \multicolumn{2}{|c|}{$\begin{array}{l}\text { Compliance With } \\
\text { The Rules }\end{array}$} & \multirow[t]{2}{*}{$t_{1}$} & \multicolumn{2}{|c|}{ Against The Rules } & \multirow[t]{2}{*}{$t_{2}$} \\
\hline & & Negative & Positive & & Negative & Positive & \\
\hline \multirow[t]{3}{*}{ Moral Field } & Male & $\begin{array}{l}1.76 \\
(1.09) \\
\end{array}$ & $\begin{array}{l}1.81 \\
(1.29) \\
\end{array}$ & 0.42 & $\begin{array}{l}2.73 \\
(1.43) \\
\end{array}$ & $\begin{array}{l}1.93 \\
(1.06) \\
\end{array}$ & $5.93^{\star \star}$ \\
\hline & Female & $\begin{array}{l}1.49 \\
(0.96) \\
\end{array}$ & $\begin{array}{l}1.74 \\
(1.26) \\
\end{array}$ & 1.87 & $\begin{array}{l}2.67 \\
(1.36) \\
\end{array}$ & $\begin{array}{l}1.98 \\
(1.01) \\
\end{array}$ & $4.68^{\star \star}$ \\
\hline & $t_{3}$ & 0.51 & $2.20^{*}$ & & 0.36 & -0.25 & \\
\hline \multirow[t]{3}{*}{$\begin{array}{l}\text { Customary } \\
\text { Field }\end{array}$} & Male & $\begin{array}{l}2.44 \\
(1.27) \\
\end{array}$ & $\begin{array}{l}2.45 \\
(1.35) \\
\end{array}$ & 0.10 & $\begin{array}{l}2.38 \\
(1.38) \\
\end{array}$ & $\begin{array}{l}1.75 \\
(1.05) \\
\end{array}$ & $4.66^{\star *}$ \\
\hline & Female & $\begin{array}{l}2.35 \\
(1.24) \\
\end{array}$ & $\begin{array}{l}2.12 \\
(1.15) \\
\end{array}$ & 1.68 & $\begin{array}{l}2.17 \\
(1.33) \\
\end{array}$ & $\begin{array}{l}1.67 \\
(1.00) \\
\end{array}$ & $3.77^{\star \star}$ \\
\hline & $t_{4}$ & 0.55 & $2.19^{*}$ & & 0.69 & 1.30 & \\
\hline \multirow[t]{3}{*}{$\begin{array}{l}\text { Personal } \\
\text { Field }\end{array}$} & Male & $\begin{array}{l}3.34 \\
(3.60)\end{array}$ & $\begin{array}{l}2.47 \\
(1.41)\end{array}$ & $2.81^{* *}$ & $\begin{array}{l}2.20 \\
(1.50)\end{array}$ & $\begin{array}{l}2.14 \\
(1.37)\end{array}$ & 0.43 \\
\hline & Female & $\begin{array}{l}2.92 \\
(1.43)\end{array}$ & $\begin{array}{l}2.33 \\
(1.26)\end{array}$ & $3.86^{\star *}$ & $\begin{array}{l}2.46 \\
(1.61)\end{array}$ & $\begin{array}{l}2.05 \\
(1.27)\end{array}$ & $2.72^{\star \star}$ \\
\hline & $t_{5}$ & 1.31 & 0.89 & & -1.40 & 0.57 & \\
\hline
\end{tabular}

Note: $t 1, t 2$ are the differences in the intentional judgment of the same sex subject under the two side effects in the same field in the case of obeying the rules and breaking the rules. $t 3, t 4, t 5$ are morality, custom and individual respectively. Differences in intentional judgments in the field under the same side effects. The effect amount $d$ is before $0.59-0.74$ and the effect amount is above medium.

Table 4. Results of Repeated Measures Analysis of Variance with Intentional Judgment Results as Dependent Variables.

\begin{tabular}{lll}
\hline & $\boldsymbol{F}$ & $\boldsymbol{\eta}^{2}$ \\
\hline Grade & $4.80^{* *}$ & 0.039 \\
\hline Domain Type & $22.92^{\star *}$ & 0.053 \\
\hline Domain Rules & $3.99^{* *}$ & 0.005 \\
\hline Side Effect Condition & $82.98^{\star *}$ & 0.091 \\
\hline Field Rules * Grade & $2.85^{* *}$ & 0.024 \\
\hline Domain Rules * Domain Type & $60.41^{* *}$ & 0.128 \\
\hline Side Effect Condition * Grade & 1.95 & 0.091 \\
\hline Side Effect Condition * Field Type & 0.090 & 0.002 \\
\hline Field Type * Grade & 1.18 & 0.020 \\
\hline Domain Rules * Side Effects & $4.31^{*}$ & 0.005 \\
\hline Domain Rules * Grade * Field Type & $2.64^{* *}$ & 0.043 \\
\hline Side Effect Condition * Grade * Field Type & 1.34 & 0.022 \\
\hline Domain Rules * Side Effects * Field Type & $13.94^{\star *}$ & 0.033 \\
\hline Domain Rules * Side Effects Conditions * Domain Types * Grades & 0.92 & 0.015 \\
\hline
\end{tabular}


tion of the four variables is not significant. In terms of the amount of effect, the main effect of side-effect conditions and the interaction between side-effect conditions and grades were the greatest. From the results of the analysis of variance, it can be seen that there is a difference in the intent judgment results in the grade. Through further postcomparison comparisons, the differences in intentional judgments are as follows: seventh grade $>$ eighth grade, seventh grade $>$ tenth grade, ninth grade $>$ twelfth grade, eleventh grade $>$ tenth grade, eleventh grade $>$ twelfth grade, tenth grade in vocational high school $>$ tenth grade in general high school and twelfth grade in general high school. It shows that the tendency of juvenile intentions to judge from middle school to high school is generally declining, but there is tortuousness. The high school stage has an inverted U-shaped development trend; vocational high school students are more inclined to make intent judgments than general high school students.

\section{The Relationship between Intention Judgment and Behavior- al Nature, Evaluation of Reward, Punishment Characteristics, and Motivation}

The relationship between intention judgment and behavioral nature, behavioral reward and punishment evaluation, and behavioral motivation is analyzed. The results are shown in Table 5.

From Table 5, we can see that in the ethical field, the intention judgment is most significant in relation to the secondary motivation. When the field rules are followed, the intention judgment is significantly correlated with the main motivation. Under the negative conditions of the compliance field, the intention judgment and reward and punishment feature correlation is significant. In the customary field, intentional judgment is significantly associated with secondary motivation only when the rules of the field are observed. In the personal field incidents, under the negative conditions of complying with the rules of the field, the intention judgment is significantly related to the behavior evaluation, behavior reward and punishment characteristics, and secondary motivation. Under the condition of violating the rules of the field, there is a significant positive correlation between intention judgment and behavior evaluation and secondary motivation, but it is negatively correlated with the main motivation. In summary, the related variables in the three domain types have related variables, which are secondary motivations. The behavioral evaluation and behavior reward and punishment characteristic variables are significantly related to the intention judgment in the personal field events.

\section{Discussion}

\section{The Overall Characteristics of the Knobe Effect of Adoles- cents in a Single Field}


Table 5. Correlation between Intention Judgment and Behavior Evaluation, Reward and Punishment Characteristics, Main Motivation, and Secondary Motivation.

\begin{tabular}{|c|c|c|c|c|c|c|c|}
\hline $\begin{array}{l}\text { Domain } \\
\text { Type }\end{array}$ & $\begin{array}{l}\text { Rule } \\
\text { Type }\end{array}$ & $\begin{array}{l}\text { Condi- } \\
\text { tion }\end{array}$ & & $\begin{array}{l}\text { Behav- } \\
\text { ioral } \\
\text { Evalua- } \\
\text { tion }\end{array}$ & $\begin{array}{l}\text { Reward and } \\
\text { Punishment } \\
\text { Characteris- } \\
\text { tics }\end{array}$ & $\begin{array}{l}\text { Main } \\
\text { Motiva- } \\
\text { tion }\end{array}$ & $\begin{array}{l}\text { Second- } \\
\text { ary Moti- } \\
\text { vation }\end{array}$ \\
\hline \multirow{4}{*}{$\begin{array}{l}\text { Moral } \\
\text { Field }\end{array}$} & \multirow{2}{*}{$\begin{array}{l}\text { Comply } \\
\text { With }\end{array}$} & Pos. & \multirow{4}{*}{$\begin{array}{l}\text { Inten- } \\
\text { tional } \\
\text { Judg- } \\
\text { ment }\end{array}$} & 0.054 & 0.022 & $-0.235^{\star \star}$ & $0.366^{\star *}$ \\
\hline & & Neg. & & -0.002 & $0.259^{\star \star}$ & $-0.166^{\star \star}$ & $0.259^{\star \star}$ \\
\hline & \multirow{2}{*}{$\begin{array}{l}\text { Viola- } \\
\text { tion }\end{array}$} & Pos. & & -0.016 & 0.075 & 0.028 & -0.024 \\
\hline & & Neg. & & 0.101 & 0.075 & -0.058 & $0.201^{* *}$ \\
\hline \multirow{4}{*}{$\begin{array}{l}\text { Custom- } \\
\text { ary Field }\end{array}$} & \multirow{2}{*}{$\begin{array}{l}\text { Comply } \\
\text { With }\end{array}$} & Pos. & \multirow{4}{*}{$\begin{array}{l}\text { Inten- } \\
\text { tional } \\
\text { Judg- } \\
\text { ment }\end{array}$} & -0.062 & 0.112 & -0.085 & $0.169^{\star \star}$ \\
\hline & & Neg. & & -0.039 & 0.231 & -0.098 & $0.302^{* \star}$ \\
\hline & \multirow{2}{*}{$\begin{array}{l}\text { Viola- } \\
\text { tion }\end{array}$} & Pos. & & 0.082 & -0.037 & -0.014 & 0.059 \\
\hline & & Neg. & & -0.071 & -0.027 & -0.015 & 0.016 \\
\hline \multirow{4}{*}{$\begin{array}{l}\text { Personal } \\
\text { Field }\end{array}$} & \multirow{2}{*}{$\begin{array}{l}\text { Comply } \\
\text { With }\end{array}$} & Pos. & \multirow{4}{*}{$\begin{array}{l}\text { Inten- } \\
\text { tional } \\
\text { Judg- } \\
\text { ment }\end{array}$} & -0.126 & 0.050 & 0.066 & $0.174^{\star \star}$ \\
\hline & & Neg. & & $-0.216^{\star \star}$ & $0.181^{\star \star}$ & 0.050 & 0.032 \\
\hline & \multirow{2}{*}{$\begin{array}{l}\text { Viola- } \\
\text { tion }\end{array}$} & Pos. & & $0.469^{* *}$ & $0.421^{* *}$ & -0.016 & $0.368^{* *}$ \\
\hline & & Neg. & & $0.115^{\star}$ & 0.084 & $-0.138^{*}$ & $0.294^{\star \star}$ \\
\hline
\end{tabular}

This study examined the characteristics of intentional judgment under different sideeffects of different and single-field events. The results showed that the Knobe effect in the three fields is very significant in the case of violation of the domain rules, and in the case of compliance with the domain rules, the Knobe effect is significant only in the personal field. Explain that the Knobe effect is significant in violations of domain events, and that compliance with domain events is only significant in the personal domain. Judging from the same side-effects, in addition to the negative conditions in the customary field, differences in the judgment of side-effects in the field of compliance and violations in the various fields and conditions have occurred; the side-effects of the violation of the field are more likely to be judged as intentional as the side-effects of the field. Nucci (1981) found that children can distinguish between events or rules in the moral, custom, and personal spheres from the age of seven. They usually think that the moral violation is the most serious, and the second is the violation of the custom. When there is no rule to bind the behavior, it also believes that the moral violation is wrong and can recognize the compulsory, normative and universal nature of the moral field. But there is more flexibility in customs and personal events. The results of this study demonstrate once again that the Knobe effect is related to ethical evaluation, because events that violate domain rules tend to be negatively evaluated more.

The development of cognitive ability in the field of ethics and custom is mainly manifested in the further deepening of children's understanding of rules, and the development of personal field shows various changes with the increase of children's age. As children age, their ability to act continues to improve and self-awareness continues to increase, they show strong personal needs, and thus the phenomenon of personal rights 
expansion in the later stages of adolescence (Nucci \& Turiel, 2009). Adolescents believe that teachers and schools have legitimate authority to develop and enforce rules on customary issues (Weston \& Turiel, 1980; Dodsworth-Rugani, 1983; Blumenfeld et al., 1987). Most of them can accept the customs and rules of care set by the school and the teacher, and do not recognize violations. Compared with junior high school students, high school students tend not to accept the personal field specified by others, and they believe that personal events that violate the rules are allowed. Adolescents' perceptions of events in different fields are related to the corresponding actors. They tend to think that teachers should not interfere too much with students' individual behaviors, and some teenagers can accept personal domain events as defined by their peers (Smetana \& Bitz, 1996; Wang, 2008; Liu, 2009). We found that in the case of compliance with the rules of the field, the Knobe effect is significant only in the personal field, and it also reflects the importance that young people attach to the rules of the personal field.

Children aged 2-3 begin to be able to distinguish between rules regulating actions in different fields. The judgement of children in the field of ethics and customs in the age of 4-9 is influenced by the field and the makers of the rules. Children aged 12 and 14 emphasize the psychological state of the individual in their understanding of the rules of the field of ethics and customs, emphasizing the satisfaction of self-wish and the existence of personal preferences or tendencies. Children in this period have a tendency to deny social customs and social traditions. Their understanding of social customs is to constantly affirm and continually negate the development of twists and turns (Zhang et al., 1998). From middle school to high school is an important period for individuals to expand their personal field. Personal choice is particularly important for the adolescent stage because it provides opportunities to develop individuality, autonomy, and unity (Nucci, 1996; Nucci, 2003), which is the most important development task for adolescents.

\section{Intra-Group Differences in the Knobe Effect of Adolescents in a Single Field}

The gender difference comparison found that the ethical field and the customary field of the positive side-effects of the field rules were significantly different between males and females, and the males were more inclined to think that the actors were intentional. The side effects of positive conditions are good results. Boys tend to think that actors have intentionally brought good results. Girls' evaluations are more conservative and objective, indicating that girls are more rational than boys. However, there is no difference in the personal field. Du's (2011) research showed that no matter whether it is under positive or negative conditions, males are more inclined than females to judge that actors are intentional. The results of this study are the same. There is a consensus in previous studies, but under negative conditions, there is no difference between men and women, indicating that gender variables as an influential factor are inconsistent. The results of this study may be that male adolescents are more unilateral than female adolescents in understanding behavioral intentions. 
Under different domain types and different domain rules, the intent to judge side effects is different in the grade. The intention of judging the junior high school is the highest, and it falls after high school, but the eleventh grade is the highest, and the thirteenth grade is obviously reduced. This is consistent with the development of the juvenile moral judgment. From the junior high school to the high school morality, the intuitive moral judgment Excessive to complex moral understanding, while in high school, moral development presents a certain inverted U-shaped development model, which does not increase with age (Liu, 2013, Nucci \& Turiel, 2009). The age development result of the intentional judgment in this study is consistent with the development result of moral judgment, that is, the higher the level of moral cognition, the more intentional judgment becomes rational, and the judgment of intentional tendency is reduced, which confirms the relationship between Knobe effect and moral judgment.

\section{The Relationship between Juvenile Side-Effect Intention Judgment and Motivation Evaluation in a Single Field}

Among the three single-domain events, the variables related to the consent graph judgment are secondary motivations, and the behavioral evaluation and behavior reward and punishment characteristic variables are significantly related to the intention judgment in the personal field events. The results again show that the motivation for judging the behavior of the actor is also intentional, but the behavioral evaluation and behavioral reward and punishment characteristic variables are only relevant in the personal field event, and in the ethical field and the customary field. Seeing peers is significantly related to the evaluation or reward and punishment characteristic variables. This is because in the field of ethics and customs, the moral situation is clearer, the subjects tend to make extreme judgments, and the intention judgment is more scattered, so the degree of correlation is low, but The moral situation in the personal field is relatively vague, and the judgments on the behavior evaluation and behavior reward and punishment characteristics are also scattered, so the consent chart judgment is significant. This result verifies the moral utility theory of Knobe effect. The more serious the violation of the field, the easier it is to be judged as intentional and the role of morality.

\section{Conclusion}

The study found that: (1) Knobe effect is affected by domain type and domain rules in a single field event. When the domain rules are violated, the Knobe effect is shown in the three domain events, and in the case of complying with the domain rules, only Knobe effect in the personal field (2) The performance of the Knobe effect in a single field event is different in gender and grade. (3) Variables related to intentional judgment in three single domain types are secondary motivations. The behavioral evaluation, behavioral reward and punishment characteristic variables are significantly related to the intention judgment in the personal field events. 
The discussion of the mechanism of Knobe effect also demonstrates two interpretations. Although the control variables have been implemented and the hypothesis of the dual model mechanism has been proposed, the actor bias theory and the moral valence theory have not been placed in the same experimental framework. How do you specifically influence the Knobe effect and how much impact each other? In addition, the age range only covers adolescents. From a developmental point of view, it is best to have children from 4-12 years old to be more comprehensive.

The results of the study indicate that the Knobe effect is influenced by the evaluation of behavioral ethics, which suggests that we must avoid the misunderstanding of intentions caused by the Knobe effect, which can be weakened by the actor and behavioral ethics evaluation, such as teachers are formulating certain regulations, but the regulations will produce a certain impact on students. It can be exemplified that the peer group also abides by, or morally, adhering to the rule is highly ethical.

Therefore, adolescents have only an incomplete Knobe effect in a single-field event, and their performance is influenced by domain rules.

\section{References}

Blumenfeld, P.C., Pintrich, P.R., \& Hamilton, V.L. (1987) Teacher talk and students' reasoning about morals, conventions, and achievement. Child Develop, 58:13891401.

Chen, Y., \& Yan, H. (2013) The development of middle school students' theory of mind in moral context. Stud Psychol Behav, 11(4):483-489.

Dodsworth-Rugani, K.J. (1983) The development of concepts of social structure and their relationship to school rules and authority. Dissert Ab Int, 43(8):2602.

Du, X. (2010) Discussion on the verification and internal mechanism of Nob effect. Master's thesis, Zhejiang: Zhejiang Univ.

Knobe, J. (2003) Intentional action and sideeffects in ordinary language. Analysis, 63:190-194.
Knobe, J., \& Mendlow, G. (2004) The good, the bad and the blame worthy: Understanding the role of evaluative reasoning in folk psychology. $\mathrm{J}$ Theor Philos Psychol, (24):252-258.

Liu, G. (2009) Adolescents' differentiation of events in different fields. J Xuzhou Norm Univ : Philo Soc Sci, 35(4): 110-114.

Nucci, L., \& Turiel, E. (2009) Capturing the complexity of moral development and education. Mind Brain Edu, (3):151-161.

Nucci, L. (1981) Conceptions of personal issues: A domain distinct from moral or societal concepts. Child Develop, 52:114121.

Nucci, L., Liu, C., \& Xie, G. (2003) Education in the field of morality. Harbin: Heilongjiang People's Publishing House. 
Lin et al. Influence of Cognition on the Knobe Effect in Juveniles.

Smetana, J.G., \& Bitz, B. (1996) Adolescents' conceptions of teachers' authority and their relations to rule violations in school. Child Develop, 67(3):1153-1172.

Wang, X. (2010) Adolescent field differentiation research. Master's thesis. Shanghai: Shanghai Nor Univ.
Weston, D.R., \& Turiel, E. (1980) Act-rule relations: children's concepts of social rules. Develop Psychol, 16(5):417-424.

Zhang, W., Xu, T., \& Wang, S. (1998) Distinction and cognition of moral rules and social customs among children aged 6-14 in China. Psychol Develop Edu, (1):21-25.

Received: 12 September 2019

Revised: 20 September 2019

Accepted: 09 October 2019 